\title{
Examining the Opinions of Teachers of Adolescent Students with Mental Deficiencies Towards Sexual Education
}

\author{
Tara Yektaoglu-Tomgüsehan ${ }^{1^{*}}$, Gönül Akçamete ${ }^{1}$ \\ ${ }^{1}$ Near East University, Nicosia, N. CYPRUS
}

Received 19 September 2017 • Revised 12 October 2017 • Accepted 15 October 2017

\begin{abstract}
It is very important for the teachers to know the sexual abuse and harassment as they are people who know and best communicate with the individual after their families and to transform the inappropriate behaviors of the students towards their personal sexual behaviors, against one another or their peers into good behaviors in order to prevent future negative effects. Knowing the appropriate and non-appropriate sexual behavior of students with mental deficiencies will guide the determination of the content of the program. The purpose of this study was to examine the opinions of the adolescents with mental deficiencies on their in-school experiences and on the in-school training and abuse issues. Six teachers who provided education in schools of students with mental deficiencies were involved in the research. The results showed that teachers had inadequate education about sexual education both during university education and inservice training, and that the students showed inadequate behaviors in the classroom environment due to lack of information and education deficiencies. It is also seen that the teachers do no have enough knowledge about the mentally retarded adolescents showing proper sexual behavior.
\end{abstract}

Keywords: mental deficiency, adolescent, sexual education, teacher, sexual harassment and abuse

\section{INTRODUCTION}

Nowadays, it is stated that giving sexual education to individuals at an early age will provide a healthier sex life in adulthood (Çalışandemir, Bencik, Artan, 2008). Sexual education is a process that begins with birth and develops and continues throughout the individual's whole life. Sexual education is an educational program designed to encourage individuals to understand both physical and emotional sexual development, develop a positive selfawareness, empathize with their own sexuality, the rights of others around them, their opinions and behaviors, and develop judgements of meaning and value (Artan, 2002). Sex education is also aimed at helping children and adolescents to accept boys and girls roles and to help them live in harmony with the characteristics of their fellow and opposite gender (Çalışandemir, Bencik, Artan, 2008; Çok, 2003; Öztürk, 2013).

Sexual abuse is defined as a sexual behavior between a child and another child who is older or a child who has not completed psycho-social development is being used by any adult for sexual arousal (Küçük,2012). Defining the concept of abuse of the World Health Organization (WHO), the following three arguments have to be taken into account; first the child, then the abuser, and finally the effect of the abuse on the child. The World Health Organization also notes that gaining control over a child as well as the sexual satisfaction of adult individuals at the same time as sexual exploitation is a problem of abused trust and power (Bilgin, 2015). Sexual education is one of the most important ways to prevent sexual abuse in children and adolescents (Çeçen, 2007). Within the framework of formal education it should be ensured that children and adolescents at risk are informed about sexual abuse, their awareness and sensitivities are developed, and thus the possibilities of exposure to abuse should be abolished.

The Child Abuse Prevention Association, which is actively working in the United States defined sexual abuse as a situation in which a child under the age of consent of sexual exploitation takes part in or takes the place of an 


\section{Contribution of this paper to the literature}

- In order to provide instruction on sexual education for students with mental deficiencies and adolescences, there is a need for scientifically based practices in determining effective teaching methods.

- With this study, it is expected that teachers will be aware of sexual education and they will be able to support their students in sexual education.

- It is thought that the study will shed light on the sexual education programs to be developed for students with mental disabilities.

act that would lead to a sexual satisfaction of a sexually mature adult. (Child Abuse Prevention Association, 2000). Many features of sexual abuse are mentioned as; verbal abuse, spoken phone conversations, exhibitionism, voyeurism, witnessing sexual intercourse, touching the body for sexual purposes, subjecting obscene publications, forcing prostitution, raiding, rape, domestic sexual abuse (Çeçen, 2007; Hoşoğlu, 2009; Soylu, Pilan-Şentürk, Ayaz, Sönmez, 2012; Bağ, Alşen 2016). In addition to being affected physically, socially and emotionally, a person who has suffered a sexual abuse as well as the indvidul's family is exposed to the destructive effects (Bilgin, 2015; Soylu et. al. 2012). Despite the frequent occurrence of sexual abuse and its effects, it is often confidential because of the shame it causes and the feeling of guilt towards one's self. (Soylu et. al 2012; Bağ, Alşen 2016). As well as individuals with special needs all children and young people in the society are exposed to sexual exploitation. Those with mental deficiencies are exposed to more abuse (Akkuş, 2014; Soylu et. al. 2012; Hoşoğlu, 2009; Küçük, 2012).

According to Watson (1984), deprivation of judgment and social skills of individuals with mental deficiencies increases sexual abuse. (Lumley, Milternberger, Long, Rapp, Roberts, 1998). If individuals with mental deficiencies have communication problems, it is stated that the individual will not be able to request help in the event of a sexual threat and will not be able to report bad behavior to him. The most important reason for this is the lack of information about the communication problem as well as the protection of the individual against abuse and the lack of appropriate sexual behavior training (Lumley et. al. 1998; Tang, Lee 1999). In addition, adolescents with intellectual disabilities are considered to be the likely childlike states, unable to predict the outcome of their actions or the actions they come across, their inability to control internal reactions, and the causes of sexual abuse (Hoşoğlu, 2009).

According to some researches conducted in the literature, the problems experienced by individuals who have been exposed to sexual abuse increase depending on some variables. The mentioned variables are close to the victim of the perpetrator the duration of abuse, the use of force and the intensity of abuse, and the extent to which parents the proportion of individual support and the ability to cope with what the individual lives. In this context, an individual with intellectual disability who is suffering from sexual exploitation can lead to long-term problems in the victim who are not supported, accused or criticized (Bilgin, 2015). However, many of the sexual abuse factions are made up of people who are known and trusted by individuals with mental disabilities. In his work Küçük (2016) has indicated that sexual abuse agents are composed of persons in the immediate vicinity of children. It is therefore necessary to increase awareness of sexual abuse among children with mental deficiencies in every part of society we live in. In this way, children can be protected from any sexual neglect and abuse that they may be exposed to (Küçük, 2012; Kim, 2010).

The general aim of the study is to examine the opinions of teachers of adolescent students who have been diagnosed with mental deficiencies towards sexual education. It is often not possible for students to observe their surroundings and to obtain accurate and necessary information from written sources. For this reason, students with intellectual disabilities need to be guided by the individuals in their surroundings (Yurdakul, 1999). Therefore, it is thought that the study to be done will shed light on the sexual education studies aimed at making students who are adolescents who are mentally disabled. Students with intellectual disabilities should be taught to identify possible sexual exploitation protection skills as well as signs ofabuse (Karanfiloski and Trajkovski,2008). Studies conducted for this purpose prevent any trauma that students with mental deficiencies in adolescence can experience (Doğru, 2008).

\section{METHOD}

This research consisted of sexual education content which was developed by the researcher and directed towards the teachers of the adolescent students who had mental disabilities. It is a descriptive research aimed to determine the level of knowledge and attitudes of teachers about sexual education in the direction of questions to be asked. In the interviews, firstly the identity information of the teachers who participated in the interview was obtained and then the questions were answered with the interview form containing semi-structured questions. At the same time, questions related to sexual education were directed in the interview form. The following views from interviewees were collected; adolescents with mental deficiencies need to consider the educational situation and 
possibilities of sexual education, the views on what sexual education content should be and the opinions of students about what is appropriate and inappropriate behavior and whether they observe any negative or positive sexual behavior with students with mental disabilities, opinions about the counter reactions, the ability to cope, the ability to solve problems, and the shortcomings in the area.

\section{PARTICIPANTS}

Based on volunteerism, six mental disailities teachers working in the special education school participated in the study. Teachers' identity information is as follows;

\begin{tabular}{lccccc}
\hline Interviewer & Gender & Field & Age & Nationality & Term of duty \\
\hline 1. Interviewer & F & Special Education & 30 & TRNC & 9 Years \\
\hline 2. Interviewer & F & Psychology & 30 & TRNC & 7 Years \\
\hline 3. Interviewer & F & Teacher for Mentally Disabled & 26 & TRNC & 3 Years \\
\hline 4. Interviewer & F & Psychological Counseling and Guidance & 32 & TRNC & 6 Years \\
\hline 5. Interviewer & M & Turkish & 32 & TRNC & 8 Years \\
\hline 6. Interviewer & F & Special Education & 32 & TRNC & 10 Years \\
\hline
\end{tabular}

In the study conducted, five of the six interviewees were female. The degree programs in which teachers graduate vary widely; two of the teachers graduated from the special education department and the other branches are composed of psychology, teachers of mentally disabled, psychological counseling and guidance, and Turkish. Except for one of the teachers, age range for the remaining is 30 years and over. Also the duty periods of interviewed teachers vary between 3 and 10 years.

\section{DATA COLLECTION TOOL AND DEVELOPMENT}

In this study, semi-structured interview questions developed by the researcher were used to obtain teachers' views on sexual education. Partcipation was based on voluntarinism. An explanation for the interviews was prepared and the aim of the study and how the study will be conducted was explained in a clear way. It was also emphasized that the identities of participants in the interviews will be hidden. Written interview forms were used during the interviews.

8 answers were sought in line with the main objective of the research. In summary the questions were; whether or not teachers have any education about the sexual education of mentally disabled adolescents, what the content of sexual education should be, what are the appropriate and non-appropriate sexual behaviors, whether the students in the class observe any inappropriate sexual behavior or not, if it is observed what these behaviors are, what is the reaction to the observed inappropriate behavior, how the teachers resorted to a way when they could not cope with the inappropriate behavior of the student, the attitudes of teachers in order to be able to describe possible verbal or physical harassment and how the behavior should be, and finally, the shortcomings of sexual education.

In order to obtain external validity in the research, examples were given from the answers provided by the teachers to the interview questions, so that "direct quotations" were made and transferability of the research was determined. For external reliability, the data obtained in the research and the results and interpretations reached in the direction of these data have been presented to the review of the field expert and it has been determined according to the opinion of this person that the obtained themes are appropriate. Validity is related to the correctness of scientific findings and reliability is related to the reproducibility of scientific findings (Yurdakul, 2006).

\section{ANALYSIS OF DATA}

The themes obtained from the data collected in the study are summarized and interpreted according to content analysis. Following the identity information of the interviewed individuals, opinions on sexual education were organized and described.

\section{RESULTS}

This study was conducted in order to examine the opinions of teachers of adolescents with mental deficiencies on sexual education. 
The findings were analyzed according to the opinions of the teachers of adolescents with mental retardation on sexual education and (sexual education knowledge, sexual education content, awareness of behavior and environmental factors, inappropriate sexual behaviors, teacher reactions to inappropriate sexual behaviors, methods of coping with inappropriate behaviors, teachers' behaviors) and attitudes towards students, each question was analyzed in the direction of opinions and 8 themes were determined in total. These 8 themes were later categorized. Discussions on each category were included. This section will first include findings on teachers' credentials and educational backgrounds, and then on information about sexual education for students with intellectual disabilities. Findings obtained in the research are presented based on the answers given to the mentioned 12 questions. The figures in parentheses are written to show which of the original narratives the teachers had at the interviews.

\title{
Teachers' Opinions about "Sexual Education Information"
}

Teachers were first asked whether they had received any education in the field of sexual education and the contents of these educations. Four of the teachers stated that they had received in-service training on sexual education and 1 said that they had sex education within the scope of the university course they studied. However, they pointed out that in-service training and lessons were inadequate and short term.

\begin{abstract}
(V1) "It was in the undergradute period. thas been a long time. I did not use these topics because I worked in pre-school integration. I can only say what I remember; it was always emphasized that this was a natural process, they said that there was nothing to hide and it should be taught to all the children, there were some things they even showed to apply, especially for boys. These are the things I remember."
\end{abstract}

(V2) "I had a day education called sexing in children on sexual education by Ayten Düzkantar. The training included more known things and there was not much detail."

(V4) "Yes, I did. In fact, education was all about sexual education. So sexual education was in the basic concept. The subject of sexual education of a mentally disabled individual was at a level of general information content without being elaborated on such a case."

(V5) "The education I received was the title of sexual education in mentally disabled. But it did not make any sense as content. Sexual education of normal developing individuals was explained."

(V6) "I attended Ayten Düzkantar's trainings. It was short, but it did not have much content."

Teachers providing education and training in the schools of students with mental deficiencies have knowledge about child and adolescent sexual abuse as well as the inadequacy of the course and in-service training programs they have received in the field of sexual education in terms of case studies. It points to the importance of providing programs about how sexual education of children and adolescents with mental deficiencies in both university and in-service education of teachers who are teaching adolescents with mentaşl disabilities in the direction of obtained results.

Irmak and Aksel's (2015) research investigated teachers' knowledge and experience on child sexual abuse and their experiences have been examined and the results of the research stated that it is important for teachers to include sexual exploitation of children in the university they have studied or in-service training they attend. Similar findings have been found in studies conducted by Erol (2007) to assess the awareness of teachers who work in preschool educational institutions about the symptoms of physical abuse in children as the studies conducted by Dereobalı, Çıralı-Karadağ and Sonmez (2013) on preschool teachers' views on child abuse, neglect, violence and the role of educators. In summary, studies in the field show that teachers do not have enough knowledge about the subject.

\section{Teachers' Opinions about "Content of Sexual Education"}

In the second question, teachers emphasized that in the context of sexual education, at first there should first be information about thebody of a child with mental disabilities.

(V1) "A child should know his body. Because it is always treated as such a taboo. Therefore, getting to know your own body should take place in this process First, it should be self-explanatory so that a sexual education and sexual abuse prevention work can be done." 
(V2) "An education that starts from the age of childhood in sexual education begins with the selfdefinition of the child, that is at the ages of 3 and 4 . How to talk to these children about sexuality and give accurate information about what we should pay attention to while talking. The attitude should be clear, the privacy should be respected and the education that starts with the family should be in line with this framework."

However, they have stated that it is necessary to teach them how to be treated within the society and especially the behavior and the factors in the environment which affect the child

(V3) "Each individual should be involved in the developmental stages. At the same time, individuals should be included in the stages of sexual development separately as girls and boys. Presentation should be made with examples."

(V4) "A lot of case examples should be included in sexual education content."

Again, factors that may affect children and appropriate and non-appropriate behaviors should be included in sexual education.

(V5) "All environmental, social and personal differences of the child and any factors that may affect it should be added to the content of sexual education."

(V6) "The special need childs should be thougth when and where to masturbate anf how to protect himself/herself, and to distinguish between appropriate and non-appropriate behaviors for the teacher. It is necessary to teach how to react to inappropriate behavior so that students do not perform these behaviours in random places."

The findings highlighted the importance of teaching the sexual education contents of the teachers primarily by recognizing the body and how to behave in the society with concrete examples.

Looking at the literature, it can be seen that the teachers of students with mental deficiencies basically have the same opinion aand together with more detailed views are observed; Gonzales-Acquaro (2009) conducted a survey of teachers' opinions about sexual education in the context of online workshops on sexual information and educational counseling in the United States and with the research conducted in this field it was seen that there is a lack of information and teachers were given training on topics such as sexual development, health, interpersonal relations, love, closeness, body image / image and gender roles. Aderemi (2013) also argued that students with mental deficiencies are at risk of exposure to HIV infection due to sexual abuse, gender functionalities, sexuality deficiencies and HIV education in Nigeria, and that students should be trained in this area. Artan (2002) argues that under the heading of increased sexual education comes primarily sexual reproduction and, accordingly, sexual intercourse on the other hand, Kakavoulis (1998) thought that sexual education needs to include the differences between sexes, sexual role and identity development, interpersonal relationships, healthy personality development, prevention from danger and trauma, and emotional balance development in early childhood sexual development and education in determining the attitudes of preschool teachers. In the research conducted by Khadijeh, Khadijah, Zahra Movahed and Hamideh (2015), they have taken the views of the teachers of the adolescent students about sexual education. Teachers have often stated that the issues addressed are maturity, menstruation, hygiene and cleansing. Another topic which the teachers would like to teach is moral values and adolescents' basic rights to make life easier for students before marriage. Teachers have also argued that their education should be done by health education teachers through educational brochures. Ramiro and Matos (2008) predicted that they would divide the students into classes and provide appropriate sex education for their age. According to this, topics about body image / image should be taught primary school education, on the other hand, menstrual periods, puberty, reproductive and birth, personal security, terminology of sexual organs and sexual abuse and abuse in the fifth grade, sexually transmitted infections and AIDS in the fifth or 7-9. classes.

\section{Opinions of Teachers towards "Awareness of Behavior and Environmental Factors"}

In the third case, the teachers stated that it is a good idea for special needs individuals to fullfill their sexual urges in an environment where they are alone, like bathrooms. However, it is argued that this behavior is inappropriate when the situation is the opposite.

(V1) "I think it suits self-relieving things for proper sexual behavior. If it is appropriate age for the student masturbation is suitable. Inappropriate behaviors are, for example if you need something like masturbation to go to your roomi not to do it in society, not to try it against someone else and behaviors such as touching, kissing should only be done as long as the person's permission is obtained." 
(V2) "With appropriate behaviour the child will recognize himself and to respect sexual prosperity in private place. For example, the bathroom or his own room. For example: dressing, toilet or bath in its own room with the door closed."

(V3) "Playing improper place with special body, not touching special places of others".(...)

(V4) "First, the family should receive in-service training on this subject. Once the family is informed about this issue, there should be borders determined at home and the child should be directed accordingly. The initial informing and training process should start at home between the family and the child, to avoid touching everyone's private areas."

(V5) "What is appropriate is that the individual does their special things around his or her own designated area. Behaviors exhibited in any environment that is not their own and is not available for personal life are not appropriate."

(V6) "Yes, it is appropriate to masturbate in the bathroom or in the room where it is taught, but it is inappropriate to perform this behavior in the guest house or in the park."

Teachers also categorized the behavior of kissing and touching without persmission as inappropriate behavior

(V3) "(...). . unauthorized physical contact, unauthorized hugging, kissing, talking about sexual information in inappropriate places are behaviors that a student should not show."

(V5) "Another student's unauthorized touch is also wrong, inappropriate behavior. Kissing without permission and hugging is inappropriate behavir and it should be avoided. (...)."

Teachers stated that appropriate behavior in the direction of their observations and information about the area is appropriate behavior is to fullfill their sexual needs in places where they are alone, such as bathrooms. However, it is said that inappropriate behavior is the case of an opposite. However, kissing or trying to touch a student without permission is also classified as inappropriate behavior. Er, Bayraktar and Kesici (2016) worked on the development of a sexual education program for students in need of special education in their research situation and listed the need for special education in the sexual problems and the expectations of sexuality, excessive masturbation, the desire for marriage, the tendency to touch the opposite gnomes, the problem of adaptation to physical change in adolescents, sexual abuse. While these headings are seen as a problem, problems can be solved by special education teachers, special education students and their families; defending the need for education under the headings of removing the sexual needs of the individuals who need special education in the appropriate environment, antinomic tendency, physical change during puberty and cleaning of the sexual organs. On the other hand, Mermer (1993) listed the inadequate behavior with the research he conducted as; homosexuality, masturbation made by others, sexual abuse by hand, verbal abuse, rape of youngsters and disabilities, viewing open publications, rape, sexual intercourse with animals, sexual intercourse with group, inverse relationship.

\section{Opinions on Teachers' Inappropriate Sexual Behaviors in the Classroom}

Teachers who were interviewed in the fourth theme of the study stated that the most noticeable inappropriate sexual behaviors were playing with the sexual organ and intense hugging efforts.

(V1) "(...) we had a child who felt a constant need for hugging. To be clear, we initially perceived it differently, but when we met the family afterwards we learned that the child grew up in a very loveless environment and that the behavior of hugging was never done at home. We approached it differently, thought it was such a thing, but it did not come out in that way. (...)"

(V2) "Yes, there was a habit of constant hugging in one the students even to strangers. There are diminishes right now. Our reaction was to prevent and walk away. We observe that the hugging decreasing."

(V3) "Yes, I have observed. One of our students showed behavior in of playing with his sexual organin the classroom. At first I prenteded as if I did not see it and than I have found a moment when we were alone and I have talked to him. I told him that this was wrong and told him that he should not do it in class and the places where he can do staff something like that. It was useful."

(V4) "I have observed some behaviors in students who are at puberty level. Too much hugging instinct, constantly having the desire to talk to the opposite sex while touching." 
(V6) "(...) continuous behavior of a girl student who is studying in the classroom in the first grade of primary school. For example, she puts his chair in a crossed position and rubs her vagina for a long time in the corner of the chair. This behavior could be overcome by replacing the seats with 2-person banksAfter 7-8 months, the behavior repeats with the changing class environment. (...)"

As a result of the interviews with the teachers unsuitable sexual behavior within the class that took the teachers' attentions was determined as playing with the sexual organ, rubbing and intense hugging. There is no clear information on the subject in the field. There were no studies investigating the opinions of teachers of children and adolescents with mental deficiencies about sexual education and the inappropriate behaviors of students in class. It has been observed that inappropriate sexual behaviors of the students with mental deficiencies in the class are observed and the teachers apply various methods in order fot these behaviors to not be repeated. The reason for the students to show inappropriate sexual behavior within the class is because they do not know if these behaviors are appropriate or not. The fact that these students are not taught sexual behaviors that are suitable for younger age causes adolescents to behave inappropreately in the classroom. Teachers need to inform their students with mental deficiencies about the appropriateness of the sexual behaviors they show to the class during the adolescence period.

\title{
Teachers' Views About Teacher Responses Towards Inappropriate Sexual Behavior
}

Teachers make an inference from the answers they give in the fifth theme that the methods of speaking and telling are the two most important methods that students use when they show inappropriate behaviors.

\begin{abstract}
(V1) "At first I prented as if I did not see it, but after that we talked to investigate the cause of the situation. The results of our response were positive; then he started to get permission and learned that he should get permission, if he could not get permission he did not show this behavior and there was no negative reaction. He had an urge to hug for his friends, not his teachers. Some of his friends welcomed this behavior, but some of them were complaining by sayin, "he is hugging me again".
\end{abstract}

(V2) "Depending on the situation of the child for some the reaction is different for example to be riled and for some to ignore."

(V3) "I changed direction because it was during a lesson. So he could focus on the lesson I told him in a lonely environment, that his behavior was wrong, that it was unique to us, and that it was not appropriate for him to do it in the community and that he could only do it when he was alone in his room, this attitude had a postive result."

(V4) "When I observe inappropriate behaviors, verbal warnings such as talk without touching each other, without hugging each other. We can underdtand each other in this way. However, indignation and indecency are not enforced for sure. Acting like this will reinforce the behavior."

(V6) "Since the student's age is small the masturbation is different from adult masturbation, including the answer to the problem just mentioned, preventive measures are taken instead of talking about masturbation. If the age of the student was older, than it would have moven on to the teaching process. The outcome was positive. Repetition in the second age could be overcome with changes of the seats."

Some teachers also stated that it is wrong to ignore the fact that the student plays with the sexual organ and that it is wrong to refine the current situation, while some teachers have stated that they have changed direction and ignored them in the course environment. The person being ignored will increase that behavior and the event will take on a different dimension. Ignoring can be used in students when a person can not harm themselves or others. However, the desired behavior by the individual can be taught by going through a plan and program related to sexual education. However, this does not apply to the technique of ignoring instruction or to inappropriate positions.

(V5) "When the erectile dysfunction occurs, we increase the sexual dorsiflexion and change these behaviors by changing the environment and behavior(...)"

Teachers stated that speaking and explaining methods are the two most important methods used to prevent inappropriate behaviors observed in the classroom. Again, it was said that the ignorance behavior was one of the methods teachers use. In his study of problem behaviors, Sucuoğlu (2004) stated that the teachers gave various punishments such as talking to parents, talking to the students individually, calling the counsell teacher to the class, punishing the students by not allowing them to go out in the brake time or rephending the child in order to reduce or eliminate problem behaviors. At the same time, Akalın (2005) stated that the following methods can be used in 
reducing the problem behaviors; teachers talking with students about problems, receiving help from school guidance teachers, special education teachers, field specialists, student's family, school management or colleagues.

\section{Teachers' Opinions Towards the Methods Used to Handle Inapproprite Behaviors}

In the sixth case, we see that the family has consulted the expert, especially the adult psychiatrist, when the teachers can not cope with inappropriate behaviors of the students or can not prevent them.

(V1) "As I mentioned, we discussed this wih the family before and talked to the child. We tried to solve the situation with the child, we did do any training with the other children when situation was solved. We called the family here."

(V2) "When we can not cope with inappropriate behavior, we receive help from specialists or doctors."

(V3) "Yes, I was looking for the reasons for the behavior by working in partnership with the family, responsible teacher, psychiatrist, clinical psychologist at our school."

(V4) "We are in constant communication with the adolescent psychiatrist and the family. Even when the process is over without a trouble, we are in communication. Maybe it's going to be medication, or redocarating the inside of the house. That is why we work collaboratively with both the doctor and the family."

(V5) "Sexual education is a turning point in the child's life. It is one of the most important trainings. With in a wrong teaching. we may encounter behaviors that we can not cope with. This training should be done in coordination with the specialist, family, child and instructor."

(V6) "If I have an adolescents male student with special needs, I can still study about appropriate and non appropriate ways with social stories and similar ways but I will also get help from a male special educator for bath masturbation study."

When teachers fail to cope with inappropriate behaviors of the students, we see that the family gets help from their expert counselors, especially the adult psychiatrist. Güven and Jobs (2015) underlined that good communication between experts, school management, teachers, and the family would be effective for the right information that a child should know about sexuality. On the other hand, Mermer (1993) stated that teachers read books prepared about the field, received information from doctors and developed themselves by participating in conferences, seminars and especially educational programs to be organized on the subject. Akacan (2015) examined the views of educators working in secondary education on child abuse and stated that school guidance counselors, psychological counselors and branch teachers investigated the sexual exploitation of children in schools. In particular, male students stated that they had sexual behavior against girls.

\section{Opinions on Teachers' Behavior and Attitudes towards Students}

The seventh question supports the idea that when a mentally disabled child is exposed to verbal or physical abuse a teacher should be able to be moderate and make the child feel comfortable enough to talk to them instead of shouting or scaring the child.

(V1) "The child should feel comfortable with you. The child should not think this is a crime. The child should not think that you will reprove or punish him so he can be comfotable in explaining himself. We have many tabus. It is thought that the reason why many children hide the fact hat they are abused is due to the behavior of anger and fear and this is especially in children with mental disabilities."

(V3) "We can make sure that the students feel close to us by showing protective attitude without fear and approaching kindly. Otherwise they can not tell us what they want to tell."

(V4) "You can make a child tell you as a friend hile playing a game instead of acting like blaming them."

Teachers have stated that confidence is also important, and they have stated that students' trust should be earned in communication with students.

(V5) "The child will the his problem to someone he trusts. We need to prove that we have gained trust beforehand and that we are friendly to him." 
(V6) "I need to be educated on topics such as appropriate and non-appropriate / toucing - kissing, etc, and if I'm in doubt, I will create social stories and create similar cases and ask questions. I try to win the trust of him and talk about the subject as if it is a game with social stories."

It has also been argued that teachers should take specialist help from psychiatrists and psychologists after the view of the family as a priority for behaviors and attitudes towards the students.

(V1) "(...)As a precaution, we first try to find out what the event is like. Then we get the famly to join. If necessary, we solved it with the help of a professional psychiatrist or psychologist. I did not and do not wish to go through such a thing."

(V2) "I can give an example from my personal expeience; when children have problems, they come to talk with me and as a resut one of them told me about about a physical harassment and we have taken preventions with thefamily and social services."

(V3) "Teachers must speak with the help of professionals. Such as how can I make comments about it or what kind of staff can I tell."

(V5) "Complaints are filed to all the offices in case of any harassment. This is how things should work. Experts in the field should help us."

(V6) "The child should feel like telling me themselves. (...)If there is a change in student behavior that causes me to suspect, I will arrange interviews and observations with family, close environment, school environment. I want help from psychologists who have experience with special needs children."

It is stated that when a mentally disabled child is exposed to verbal or physical abuse a teacher should be able to be moderate and make the child feel comfortable enough to talk to them instead of shouting or scaring the child. It was argued that the views of the family and the help and opinions of the experts in the field should be included in this process.

In the educational guide prepared in 2008 for the prevention of child neglect and abuse for teachers and parents, in case the child is abused there should be a place for a private talk with the child so that the child can easily express himself / herself, the teacher should not be seated behind a desk during the conversation, the teacher should not touch the child without permission, the teacher should listen to the child clearly and calmly, the teacher should speak the same language with the child, encourage the child to describe the events he / she has experienced, to encourage the child with senteces such as ; "I believe you", "I'm so glad you told me", "This is not your fault", "Abuse is not right", to put the childs words in a written format, to appreciate the child for reporting the abuse, the school or organization or local child protection agencies or authorities should be notified to report the abuse and finally the confidentiality principle should be respected. Akduman (2013) noted that violence is not a problemsolving task for students who have experienced or have been subjected to sexual abuse or neglect, that no one can touch him/her without his/her consent, the teachers' should listen to the students in an effective way, teachers should have time for their students, that the students should know the areas they live in, the people in their surroundings and most importantly the students themselves, talk about exploitation with the students and the teacher should consult the experts where necessary.

\section{Teachers' Opinions on the Missing Fields of Sexual Education}

The eighth theme of the Teachers' Opinions on the Missing Fields of Sexual Education has argued that there is no missing fields in sexual education. Teachers have emphasized that there is no education at all.

(V1) "In fact, let's not say that there are no shortcomings, there is nothing at all. As I have noted, this is my ninth year and I still have the education and knowledge I have acquired in my undergraduate degree. It did not go any further. There was no use of information at all because I also worked with young children. For example, if you take me here and send met o a place where there are adolescents, I can not do anything about it. How can I do that; with the knowledge I remember and correctness can be discussed. Ther should be something done. We were trained 9 years ago, but if we were to take an education now, it all changed a lot. Maybe what we have learnt then was wrong. Maybe it wa thing we should not have done."

(V5) "There are no missing fields in sexual education. There is no sexual education." 
In addition, it was stated that sexual education courses should be mandatory for every student and it was argued that not only children but also parents should take in-service trainings and teachers should be trained in this area.

(V2) "My view on this subject is very clear and certain; our shortcomings in the field of sexual education should be programmed by the Ministry of National Education and children should be informed about the compulsory addition of courses for sexual education in private schools."

(V3) "All staff in the school are required to receive more detailed and continuous training on sexual education. These trainings should be attended by children and the family."

(V4) "Sexual education courses, sexual education family seminars, sexual education in-service program should be given to all educated individuals."

(V5) "It is necessary to give this education to all the schools and the children to consciously continue their lives (...)"

(V6) "Of course, the curriculum should be appropriate for sexual education, every age and stage. This applies not only to children with special needs, but to all children."

At the end of the interviews, it was emphasized that there was not any lack of education in the field of sexual education, in fact there was no education, and it was emphasized that sexual education courses should be mandatory for every student and that sexual education should be done for children, families and teachers. As mentioned in the importance of sexual education in literature, it has been argued that it is necessary to carry out a wide range of researches and current situation determination in order to overcome the deficiencies in the field (Fentahun, Assefa, Alemseged, Ambaw2012; Set, Dağdeviren, Aktürk 2006), (Set, Dağdeviren, Aktürk,2006). We see that shortcomings in sexual education are demanded in in-service trainings. (Karasu, Aykut, Yilmaz, 2014a; Karasu, Aykut, Yılmaz, 2014b) Dedeoğlu, Durali and Tanrıverdi-Kış (2015) argue that the lessons planned for sexual education are important in the field and should be included in the curriculum. In studies conducted on the field, it was observed that the levels of perception of sexual information and sexual abuse by teenage girls with mental deficiencies were insignificant and that female adolescents had insufficient knowledge in terms of sexual organs, menstruation, friendship, beloved, marriage, pregnancy, birth and birth control and unwanted hugging or kissing they did not have enough knowledge about what to do or how to react in cases of sexual abuse and they had problems verbally expressing themselves. (Mandan, Sürücü, Akçin, 2010). In Baginsky's (2003) study, teachers were given training on protecting children and their teachers' views and experiences were examined. As a result of the research it has been argued that local education should be organized in order to preserve and improve the wellbeing of children and that local education systems must fulfill the tasks of protecting and promoting children's well-being. Again, Mckee and Dillenburger (2009) pointed out the importance of child sexual abuse education and child protection programs that teachers should take during their university education. Mermer (1993), on the other hand, has reached the conclusion that, in the direction of the teachers interviewed, both educators and students with mental deficiencies should participate in sexual education seminars. Güleç- Aslan Özbey, Sola-Özgüç and Cihan (2013) stated that teachers working in the field of special education said that they wanted to develop themselves on sexual education and needed education in this field. In particular, they stated that existing deficiencies could be eliminated in the framework of university education. Çoşkun and Boldan 2014 ) have studied the opinions of the special education class teacher candidates on the functioning of the certificate programs of mental deficiencies teacher education they are attendinng. In the study, the candidate teachers indicated that the lack of information in the field necessitated the introduction of sexual education courses in certificate programs. Er, Büyükbayraktar and Kesici (2016) stated that the perceptions and expectations of students with mental deficiencies should be taken into account in the determination of educational needs related to sexual development and that misunderstandings and extreme expectations should not be overlooked. It has been argued that the students need to complete the sexual development needs and to conduct the needs analysis in order to be able to choose the skills to be gained and to solve possible sexual problems. herefore, it has been emphasized that in the studies of developing sexual education program for students who need special education, it is necessary for the student to work with a family or caregiver who is in direct contact with each other, and also with field experts. 


\section{CONCLUSIONS AND RECOMMENDATIONS}

In this study, the opinions and recommendations of 6 volunteer teachers teaching at two different schools were examined in order to examine the opinions of teachers of mothers with mental deficiencies on sexual education. After the interviews it was revealed that there are many deficiencies in the field of sexual education. It has been determined that the education and studies conducted in the field of sexual education for teachers' own development are inadequate. The fact that studies in the field of sexual education are not taught to candidate teachers and teachers through in-service and in university training leads to lack of methods to prevent inappropriate behaviors. It has been stated that the content of sexual education should be informed effectively of the student and detailed with concrete examples of appropriate behaviors. At the same time, it has been argued that students observe inappropriate behaviors, both in the classroom and outside the classroom, and that they deal with these behaviors with various methods. It has been stated that teachers are in a moderate attitude towards the students and try to solve many inappropriate behaviors through communication with the students as well as the opinions of their families and experts. As a result, departments that prepare in-service training programs and seminars to the education faculties of the universities and the Ministry of National Education of the TRNC should take the shortcomings in the field and prepare trainings and programs. However, the shortcomings found in the literature suggest that further research and contribution to sexual education should be made and the deficiencies should be eliminated. It is also important to work more in the field. The lack of resources for sexual education of students with intellectual disabilities in the field is also lacking. In addition, in the education faculties of universities, it is also necessary that the comprehensive courses of sexual education are given more intensively to candidate teachers.

\section{REFERENCES}

Aderemi, T. J. (2014). Teachers' perspectives on sexuality and sexuality education of learners with intellectual disabilities in Nigeria. Sexuality and Disability, 32(3), 247-258.

Akacan, B. (2012). Ortaöğretim Okullarında Görev Yapan Eğitimcilerin Çocuk İstismarına İlişkin Görüşleri. Turkish International Journal of Special Education and Guidance \& Counselling (TIJSEG) ISSN: 1300-7432, 1(2).

Akalın, S. (2015). Kaynaştırma sınıfı öğretmenlerinin sınıf yönetimine ilişkin görüşleri ve gereksinimleri. Ankara Üniversitesi Ĕ̆itim Bilimleri Fakültesi Özel Eğitim Dergisi, 16(03), 215-234.

Akduman, G. (2013). “Öğrencim İçin" Ne Yapabilirim? Retrieved on 15 July 2017 from http://mebk12.meb.gov.tr/meb_iys_dosyalar/07/19/967821/dosyalar/2013_01/25112017_ogrencimicin. pdf

Akkuş, P. (2014). Cinsel İstismar Mağduru Kız Çocuklar: Sosyolojik ve Viktimolojik Bir İnceleme (Doctoral Thesis). İstanbul: T.C. İstanbul Üniversitesi, Adli Tıp Enstitüsü, Sosyal Bilimler Anabilim Dalı.

Aksel, E. Ş., \& Irmak, T. Y. (2015). Çocuk cinsel istismarı konusunda öğretmenlerin bilgi ve deneyimleri. Ege Ĕ̆gitim Dergisi, 16(2), 373-391.

Artan, İ. (2002). Cinsel Eğitim Etkinliklerinin Ders Programları Aracılığı ile Uygulanması. Yaşadıkça Ĕgitim, (73), 1619.

Baginsky, M. (2003). Newly qualified teachers and child protection: A survey of their views, training and experiences. Child Abuse Review, 12(2), 119-127.

Bağ, Ö., \& Alşen, S. (2016). Çocuğun cinsel istismarının değerlendirilmesinde yeni model: Çocuk İzlem Merkezleri. Behcet Uz Cocuk Hast Derg., 6(1), 9-14.

Bilgin, Ö. (2015). Cinsel istismar mağduru çocukların psiko-sosyal durumlarının istismara ait özellikler açısından tanımlanması (Doctoral dissertation). Selçuk Üniversitesi Sağlık Bilimleri Enstitüsü.

Child Abuse Prevention Association. (2000). Retrieved on 11 June 2017 from http:/ /capacares.org/

Coşkun, İ., \& Boldan, Ö. (2014). Zihinsel Engelliler Öğretmenliği Sertifika Programına Devam Eden Özel Eğitim Sınıf Öğretmeni Adaylarının Sertifika Programlarının İşlevselliğine İlişkin Görüşleri. The Journal of Academic Social Science Studies, (24), 303-318.

Çalışandemir, F., Bencik, S., \& Artan, İ. (2010). Çocukların cinsel eğitimi: geçmişten günümüze bir bakış. Eğitim ve Bilim, 33(150).

Çeçen, A. R. (2007). Çocuk cinsel istismarı: Sıklığı, etkileri ve okul temelli önleme yolları. Uluslararası İnsan Bilimleri Dergisi, 1, 1-17.

Çok, F., \& Kutlu, Ö. (2010). Ergenlerin cinsel eğitimi: Bir program denemesi. Eskişehir: Pegem Akademi. 
Dedeoğlu, S., Durali, S., \& Tanrıverdi, A. (2004). Özel Eğitim Bölümü Zihin Engelliler Öğretmenliği Anabilim Dalı 3., 4. Sınıf Öğrencileri ve Mezunlarının Kendi Bölüm Programları, Öğretmen Yetiştirme ve Eğitim Fakülteleri ile İlgili Düşünce ve Öne. Ankara Üniversitesi Ĕ̆itim Bilimleri Fakültesi Özel Ĕ̆itim Dergisi, 5(01).

Dereobalı, N., Karadağ, S. Ç., \& Sönmez, S. (2013). Okulöncesi eğitim öğretmenlerinin çocuk istismari ihmali şiddet ve eğitimcilerin rolü konusundaki görüşleri. Ege Eğitim Dergisi, 14(1).

Derneği, İ. H. (2008). Çocuk İhmali ve İstismarını Önleme Öğretmenler ve Aileler İçin Eğitim Kılavuzu. Berkay OfsetAnkara, ISBN, 978-975.

Doğru, S. S. Y. (2006). Zihin Engelli Çocuklarda Cinsel İstismar. Abant İzzet Baysal Üniversitesi Eğitim Fakültesi Dergisi.

Er, R. K., Büyükbayraktar, Ç. G., \& Kesici, Ş. (2016). Özel eğitime ihtiyacı olan öğrencilere yönelik cinsel eğitim programının geliştirilmesi. Turkish Journal of Education, 5(4), 224-234.

Erol, D. (2007). Okul Öncesi Eğitim Kurumlarında Görev Yapan Öğretmenlerin Çocuklardaki Fiziksel İstismar Belirtilerine İlişkin Farkındaliklar, Eskişehir İli Örneği (Unpublished Masters Thesis). Eskişehir: Anadolu Üniversitesi Eğitim Bilimleri Enstitüsü.

Fentahun, N., Assefa, T., Alemseged, F., \& Ambaw, F. (2012). Parents' perception, students' and teachers' attitude towards school sex education. Ethiopian journal of health sciences, 22(2).

Gonzalez-Acquaro, K. (2009). Teacher training, sexuality education, and intellectual disabilities: An online workshop. Current Issues in Education, 11.

Güleç-Aslan, Y., Özbey, F., Sola-Özgüç, C., \& Cihan, H. (2014). Vaka Araştırması: Özel Eğitim Alanında Çalışan Öğretmenlerin Sorunları ve İhtiyaçları. Journal of International Social Research, 7(31).

Hoşoğlu, R. (2009). Engelli Öğrencilerin İhmal ve İstismar Düzeyleri (Unpublished Masters Thesis). Samsun: Ondokuzmayıs Üniversitesi, Sosyal Bilimler Enstitüsü.

Kakavoulis, A. (1998). Early childhood sexual development and sex education: A survey of attitudes of nursery school teachers. European Early Childhood Education Research Journal, 6(2), 55-70.

Karanfiloski, A., \& Trajkovski, V. (2008). Sexual education for persons with intellectual disabilities. Journal of Special Education and Rehabilitation, 9(1-2), 55-66.

Karasu, N., Aykut, Ç., \& Yilmaz, B. (2014a). Zihin Engellilerin Eğitimi Anabilim Dalı Öğretmen Yetiştirme Programı Üzerine Öğretmen Görüşlerinin İncelenmesi Hearing out Teachers to Revisit Teacher Training Program for Students with Intellectual Disabilities. Hacettepe Üniversitesi Eğitim Fakültesi Dergisi, 29(4), 129-142.

Karasu, N., Aykut, Ç., \& Yilmaz, B. (2014b). Zihin engelliler öğretmenlerinin hizmet içi eğitim ihtiyaçlarının belirlenmesi. Ankara Üniversitesi Eğitim Bilimleri Fakültesi Özel Eğitim Dergisi, 15(01), 041-053.

Khadijeh, D., Khadijah, N., Movahed Zahra, P., \& Hamideh, D. (2015). Teachers' attitudes regarding sex education to adolescent. Int J Phys Beh Res, 4, 73-8.

Kim, Y. R. (2010). Personal safety programs for children with intellectual disabilities. Education and Training in Autism and Developmental Disabilities, 312-319.

Küçük, S. (2012). Hafif zihinsel engelli çocuklar ve ebeveynlerinde cinsel istismardan korunma konusunda farkındalık yaratma, Erciyes University, Institute of Health Sciences (Doctoral dissertation, PhD Thesis). Turkey.

Lumley, V. A., Miltenberger, R. G., Long, E. S., Rapp, J. T., \& Roberts, J. A. (1998). Evaluation of a sexual abuse prevention program for adults with mental retardation. Journal of applied behavior analysis, 31(1), 91-101.

Mandan Sürücü, S., \& Akçin, N. (2010). Zihin Engelli Kız Ergenlerin Temel Cinsel Bilgi ve Cinsel Istismarı Algılamalarının Belirlenmesi. 20. Ulusal Özel Eğitim Kongresi Öğretmen Yetiştirme, 21-23.

McKee, B. E., \& Dillenburger, K. (2009). Child abuse and neglect: Training needs of student teachers. International Journal of Educational Research, 48(5), 320-330.

Mermer, G. (1993). Zihin Engelli Ergenlerin Cinsel Ĕ̆itim Gereksinimleri Hakkında Anne, Baba ve Ĕ̆itimci Görüşlerinin Değerlendirilmesi (Unpublished Masters Thesis). Eskişehir: Anadolu Üniversitesi.

Öztürk, B. (2013). İlköğretim 6. Sınıf Öğrencilerine Yönelik Cinsel Eğitim Programının Etkililiğinin İncelenmesi. İzmir: Dokuz Eylül Üniversitesi, Eğitim Bilimleri Enstitüsü, Eğitim Bilimleri Anabilim Dalı, Rehberlik ve Psikolojik Danışma Bilim Dalı.

Ramiro, L., \& Matos, M. G. D. (2008). Perceptions of Portuguese teachers about sex education. Revista de Saúde Pública, 42(4), 684-692.

Set, T., Dağdeviren, N., \& Aktürk, Z. (2006). Ergenlerde cinsellik. Genel Tıp Dergisi, 16(3), 137-141.

Soylu, N., Şentürk Pilan, B., Ayaz, M., \& Sönmez, S. (2012). Cinsel istismar mağduru çocuk ve ergenlerde ruh sağlığını etkileyen etkenlerin araştırılması. Anatolian Journal of Psychiatry/Anadolu Psikiyatri Dergisi, 13(4). 
Sucuoğlu, B., Ünsal, P., \& Özokçu, O. (2004). Kaynaştırma sınıfı öğretmenlerinin önleyici sınıf yönetimi becerilerinin incelenmesi. Ankara Üniversitesi Eğitim Bilimleri Fakültesi Özel Eğitim Dergisi, 5(02).

Tang, C. S. K., \& Lee, Y. K. S. (1999). Knowledge on sexual abuse and self-protection skills: A study on female Chinese adolescents with mild mental retardation. Child abuse E neglect, 23(3), 269-279.

Tutar Güven, Ş., \& İşler, A. (2015). Sex Education and its Importance in Children with Intellectual Disabilities. Journal of Psychiatric Nursing/Psikiyatri Hemsireleri Dernegi, 6(3).

Yurdakul, A. (1999). Engelli ergenler ve cinsel eğitim. İlkışık Dergisi, 1, 1-4.

http://www.ejmste.com 